Raf. J. Sci.,Vol.28, No.2 Special Issue for the Third Scientific Conference of Chemistry, pp.10-22, 2019

\title{
Synthesis, Characterization and Antibacterial Activities of New Metal Complexes of Unsymmetrical Tetradentate Schiff Bases
}

\author{
Israa M. Al-Nidaa \\ Khnsaa Sh. Al-Nama \\ Department of Chemistry/ Collage of Science /University of Mosul
}

E-mail:*israaalnda230@yahoo.com

E-mail: al-numa3@yahoo.com

(Received 8/7/2018; Accepted 25/10/2018)

\begin{abstract}
Unsymmetrical Schiff base ${ }_{2} \mathrm{~L}^{1}=2-((8-((\mathrm{E})-1-((2-$ hydroxy phenyl $)$ ethylidene amino $)$ naphthalen-1ylimino) methyl)-6-methoxyphenol and $\mathrm{H}_{2} \mathrm{~L}^{2}=1-((\mathrm{E})-(8-((\mathrm{E})-1-(2-h y d r o x y$ phenol) ethylidene amino) naphthalen-1-ylimino)methyl)naphthalen-2-ol which derived from 1,8-diaminonaphthalene and 2-hydroxy acetophenone and then with 2-hydroxy-3-methoxy benzaldehyde or 2-hydroxy-1naphthaldehyde and their complexes of the type $\left[\mathrm{M} \mathrm{L} \mathrm{L}^{\mathrm{n}}\right]$, where $\mathrm{n}=1,2$ and $\mathrm{M}=\mathrm{Co}$ (II) $\mathrm{Ni}(\mathrm{II}), \mathrm{Cu}$ (II) and $\mathrm{Zn}$ (II) have been synthesized.Adduct complexes of the type $\left[\mathrm{ML}^{\mathrm{n}}(\text { py })_{2}\right]$ were also prepared in(1:2)(complex: py) molar ratio. The complexes and adducts were characterized by elemental analysis (C.H.N), metal content, (IR,UV-Vis, ${ }^{1} \mathrm{H}-\mathrm{NMR}$ )spectroscopy, conductivity and magnetic measurements. The resulting data suggested that the Schiff bases containing ONNO donor atoms act as dibasic tetradentate ligands through coordination with metal ions. Conductivity data in DMF solution showed that all complexes are non-electrolyte. Magnetic moment and electronic spectra dada indicate that the complexes have either squar planer or octahedral geometry, the ligands and their complexes gram negative bacteria (Salmonella typhi andEscherichia coli).
\end{abstract}

Keywords: unsymmetrical tetradentate, Schiff base, Antibacterial activity.

\section{تحضير وتشخيص مققدل جسية الفواعشيف رياعية اللن غير المتمالثلة وفعاليتها البليولوجية}

\section{الملخص}

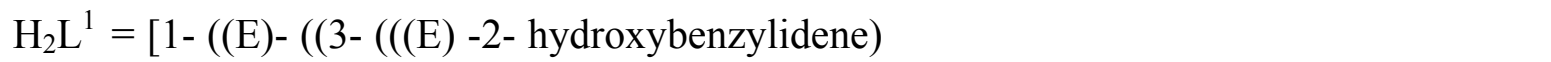
amino)phenyl)imino)methyl) naphthalene- 2- ol], $\mathrm{H}_{2} \mathrm{~L}^{2}=[1-((\mathrm{E})-((3-(((\mathrm{E})-1-(2$ - hydroxphenyl) m- والم ششقة م ethylidene) amino) phenyl) imino) methyl) naphthalene - 2 - ol], 2-hydroxyacetophenone او Salicyaldehyde 2 - hydroxynaphthaldehyde phylenediamine

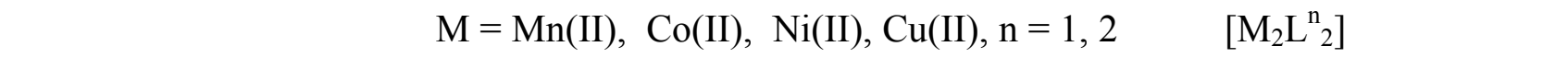

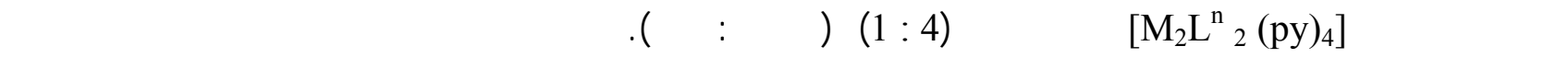

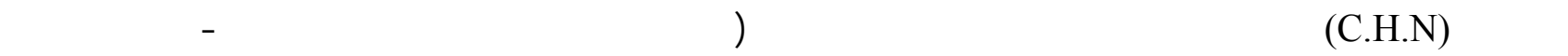

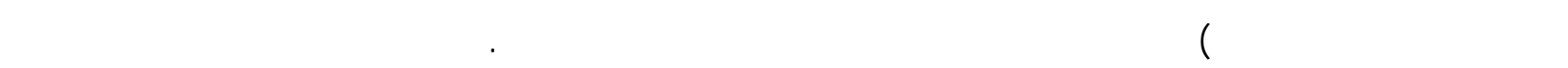

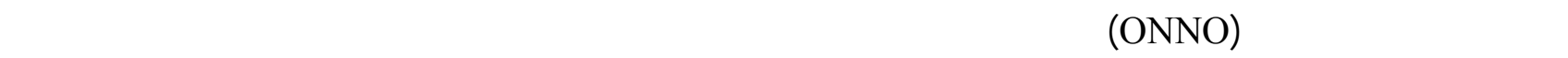
مع الايون الفلزي، بينًت نتائج قيلست التوصيلية في محلول DMSO أن المعدات غير موصلة. ومن خلل نتائج

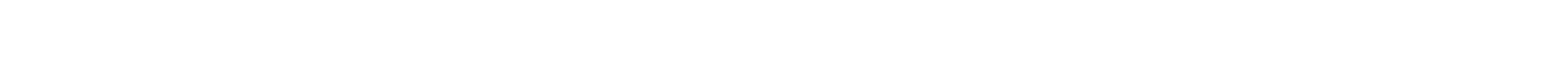

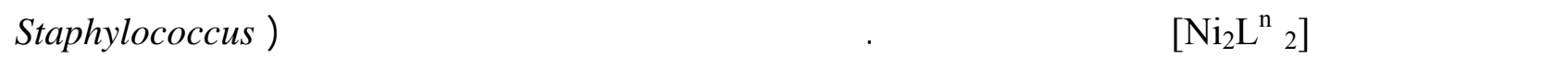
(aureus 


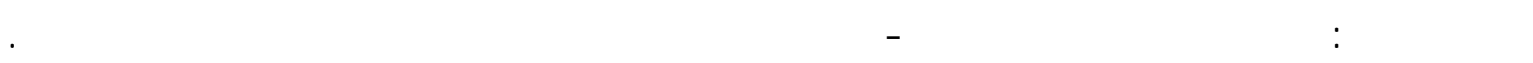

\section{INTRODUCTION}

Metal complexes of Schiff bases play a central role in coordination chemistry for analytical, physical, and biochemical purposes (Attarie et al.,1997). Both symmetrical and unsymmetrical Schiff bases and their metal complexes contributedimmensely the development ofcoordination chemistry because of structural variety, to preparative accessibility,and bioactivity(Sakunthaland Subramanian, 2012). But in biological system, transition metal ions are usually bound to a macrocycle such as heme ring or to donor atoms of peptide chains in distorted environment (Yaul et al., 2014). This unsymmetrical coordination of ligands around central metal ions had led to agrowing interest in the design and synthesis of transition metal complexes of unsymmetrical substituted Schiff base ligands as synthetic models (Nejo et al., 2009). In addition, this class of compounds presents also a wide range of interesting properties, including biological (Pandy et al., 2012), magnetic (Pietroandand and Sergio, 2004), nonlinear (NOL)(Rightto andBella, 2014), and the most commonly explored catalytic activity (Gupta and Sutar, 2007). In view of aforesaid importance of unsymmetrical Schiff bases and their complexes, we report synthesis and characterization of Schiff bases ligands $\left(\mathrm{H}_{2} \mathrm{~L}^{1}\right.$ and $\left.\mathrm{H}_{2} \mathrm{~L}^{2}\right)$ from1,8-diaminonaphthalene with 2hydroxyacetophenon the resulted compound react with 2-hydroxy-3-methoxy benzaldehyde and 2hydroxy-1-naphthaldehyde respectively.

\section{EXPERIMENTAL}

All chemicals were used reagent grad from Barco Phrma Lab companies, as supplied.Melting point or decomposition temperature was determined on Mellting point apparatus, Digital, SMP1O, and SMP2O, IR spectra were recorded on 300 spectrometer (Thermo Mattson ) (400-4000 $\mathrm{cm}^{-1}$ ) using $\mathrm{KBr}$ disc. Electronic spectra were recorded in $\operatorname{DMF}\left(10^{-3} \mathrm{M}\right)$ solution on SPECTRO UVVISAUTO, $11 \mathrm{v} 60 \mathrm{~Hz}$ or $220 \mathrm{v} .50 \mathrm{~Hz}$ at room temperature using $1 \mathrm{~cm}$ quartz cell(200-800)nm. Molar conductance was measured for $\left(10^{-3}\right) \mathrm{M}$ solution in DMF using conductivity meter JENWAY product Manuals 430/PH/cond, Meter JENWAY. Magnetic susceptibility Measurements of the complexes were carried out at $25 \mathrm{C}^{0}$ on the solid state by (Sherwood instruments). Metal content of complexes was determined spectrophotometrically using pg istroments, AA500 Atomic Absorption Spectrophotometer(Flame and graphite analysis) in Scientific Research Center. Elemental analysis of the ligands and complexes were performed on Euro EAE Elemental Analyzer EuroEA 3000Italy. ${ }^{1}$ H-NMR Spectra were recorded in DMSO-d6 using NMRedy 60 Prrouser, Manual Version 1.0(Nanalysis Crop, c 2015) in the college of Education For Pure Sciences/ Ibn Al-Haitham in the university of Baghdad.

\section{Preparation of ligands:}

The unsymmetrical Schiff base ligands were prepared according to the reported procedure (Abubakar et al., 2011). by reacting equimolar amounts of 1,8-diamino naphthalene (1.58 $\mathrm{g}, 0.01 \mathrm{~mole})$ in $(10 \mathrm{ml})$ methanol wasadded slowly to methanol solution $(10 \mathrm{ml})$ containing -2hydroxyacetophenone $(1.36 \mathrm{~g}, 0.01 \mathrm{~mole})$ and refluxed for $1 \mathrm{~h}$. Then, $(1.52 \mathrm{~g}, 0.01 \mathrm{~mole})$ of 2 hydroxy-3-methoxy benzaldehyde or (1.72 g,0.01 mole)of 2- hydroxy-1-napthaldehyde, each one dissolved in $(10 \mathrm{ml})$ methanol, the resulting colored mixture was refluxed with stirring for $4 \mathrm{~h}$ and then was cooled. The resulting precipitate was filtered off, washed with methanol and dried under vacuum, (Schem 1). 


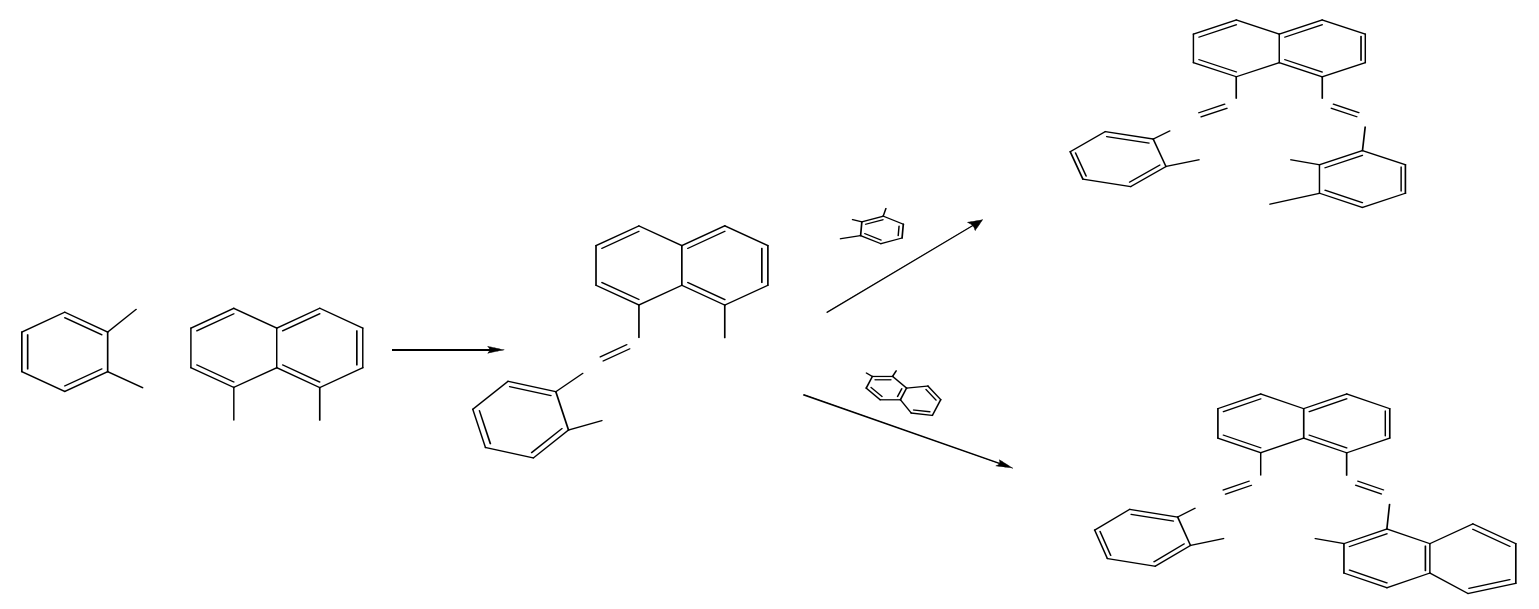

\section{Scheme 1 : Synthesis of Schiff bases ligands $\left(\mathrm{H}_{2} \mathrm{~L}^{1}\right)$ and $\left(\mathrm{H}_{2} \mathrm{~L}^{2}\right)$}

\section{Preparation of complexes}

The ligand $\mathrm{H}_{2} \mathrm{~L}^{1}(4.10 \mathrm{~g}, 0.01$ mole $)$ or $(4.30 \mathrm{~g}, 0.01 \mathrm{~mole})$ of $\mathrm{H}_{4} \mathrm{~L}_{2}^{2}$ was dissolved in $30 \mathrm{ml}$ of ethanol in $100 \mathrm{ml}$ round bottom flask. A solution of $(0.01$ mole $)$ of metal salt $\left[\mathrm{CoCl}_{2} .6 \mathrm{H}_{2}^{3} \mathrm{O}(2.37 \mathrm{gm})\right.$ $\mathrm{NiCl}_{2} .6 \mathrm{H}_{2} \mathrm{O}(2.37 \mathrm{gm}), \mathrm{CuCl}_{2} .2 \mathrm{H}_{2} \mathrm{O}(1.70 \mathrm{gm})$ and $\left.\mathrm{ZnCl}_{2}(1.36 \mathrm{gm})\right]$ in $(20 \mathrm{ml})$ of ethanol was addedwise drop for 10-15 min. with continuousstirring atkeom temp. The mixture was refluxed for (3-4) h, After cooling, the precipitate was filtered off and washed with cold ethanol then dried under vacuum.

\section{Preparation of adduct Complexes}

These complexes were prepared by the addition of pyridine $(1.58 \mathrm{~g}, 0.02$ mole $)$ to $(0.01$, mole $)$ preparedin ethanol $(50 \mathrm{ml})$ with the continuous stirring until complete precipitation (Osowole, 2008). The precipitate was filtered off, washed with ethanol and dried under vacuum.

\section{Antibacterial Activity}

Antibacterial activity was evaluated using agar diffusion method (Bauer et al., 1966)Gramnegative(Salmonella typhi and Escherichia coli). Which were cultivated in nutrient agar on petri dishes. The test solution was prepared by dissolving $(10 \mathrm{gm})$ of the tested substances in DMSO(1 $\mathrm{ml})$. A6mm diameter filter discs were socked in the tested solutions. After $2 \mathrm{~h}$ cultivation at $37^{\circ} \mathrm{C}$, dimeter of zones of inhibition was determined. DMSO was inactive under applied conditions.

\section{Result and discussion}

All the metal complexes are quite stable in dry air and insoluble in common organic solvents but soluble in DMF and DMSO.The elemental analysis shows $(1: 1)(\mathrm{M}: \mathrm{L})$ molar ratio for[M $\mathrm{L}^{\mathrm{n}}$ ] and(1:1:2) [M : $\mathrm{L}^{\mathrm{n}}:$ py]. Some physical properties of ligands and their complexes are listed in (Table 1).The molar conductance in $10^{-3} \mathrm{M}$ DMFsolution of complexes are in the range (0.4-26.18) $\mathrm{ohm}^{-1} \mathrm{~cm}^{2} \mathrm{~mol}^{-1}$, indicating a non-electrolytic nature of the complexes (Padmaja et al., 2011).

\section{IR Spectra}

The position of the important bands of Schiff bases and their complexes are shown in the (Table 2). Due to the unsymmetrical nature of the ligands and their complexes two bands were observed for each of the following groups. $v(\mathrm{C}=\mathrm{N})$; $v(\mathrm{C}-\mathrm{O})$ and $v(\mathrm{OH})$ taking their origin from the different aldehyde (Nejo et al., 2009; Hegzy and Gaafar, 2012). The ligands $\left(\mathrm{H}_{2} \mathrm{~L}^{1}\right.$ and $\mathrm{H}_{2} \mathrm{~L}^{2}$ ) exhibited characteristic $v(\mathrm{C}=\mathrm{N})$ stretching frequencies at $(1606,1625)$ and $(1610,1624) \mathrm{cm}^{-1}$ respectively, which shift to higher frequencies, upon complexation (Al-kattan and Al-Nidaa, 2014).This indicates participation of azomethine nitrogen in bonding (Arhana et al., 2007). The IR spectrum of the free ligands shows bands at $(3259,3367) \mathrm{cm}^{-1}$ and $(3243,3374) \mathrm{cm}^{-1}$ due to 
phenolic $v(\mathrm{OH})$ group for $\mathrm{H}_{2} \mathrm{~L}^{1}$ and $\mathrm{H}_{2} \mathrm{~L}^{2}$ respectively (Pethe et al., 2017). The absence of these bands in the spectra of allcomplexes and adducts indicates the coordination of phenolic oxygen to the metal after deprotonation (Munde ${ }^{1}$ et al., 2010; Yaul et al., 2009). This is further supported by the shifting of $v(C-O)$ phenolic bands $(1185,1251) \mathrm{cm}^{-1}$ and $(1234,1267) \mathrm{cm}^{-1}$ for $\mathrm{H}_{2} \mathrm{~L}^{1}$ and $\mathrm{H}_{2} \mathrm{~L}^{2}$ respectively to higher wave numbers in the complexes(Maurya et al., 2001). Thus, it can be concluded that the Schiff bases act as dibasic tetradentate ligands via the azomethine $\mathrm{N}$ and phenolic $\mathrm{O}$ atoms (Hancock and Thornton, 1969). Assignment of the proposed coordination sites is further supported by the appearance of new band at (450-481) $\mathrm{cm}^{-1}$ and $(503-580) \mathrm{cm}^{-1}$ which could be attributed to $v(\mathrm{M}-\mathrm{N})$ and $v(\mathrm{M}-\mathrm{O})$ respectively (Joel, 2015; Bagat et al., 2009). For $(5,6,7,12.13,14)$ complexes the band of $v(C=N)$ was observed at $(1473-1506) \mathrm{cm}^{-1}$ which means the coordination of the $\mathrm{N}$ atom of pyridine ring with the metal ions (Srinivasan et al., 2010).The I.R spectra of the ligands and their Ni(II) complexes have been shown in Fig1.

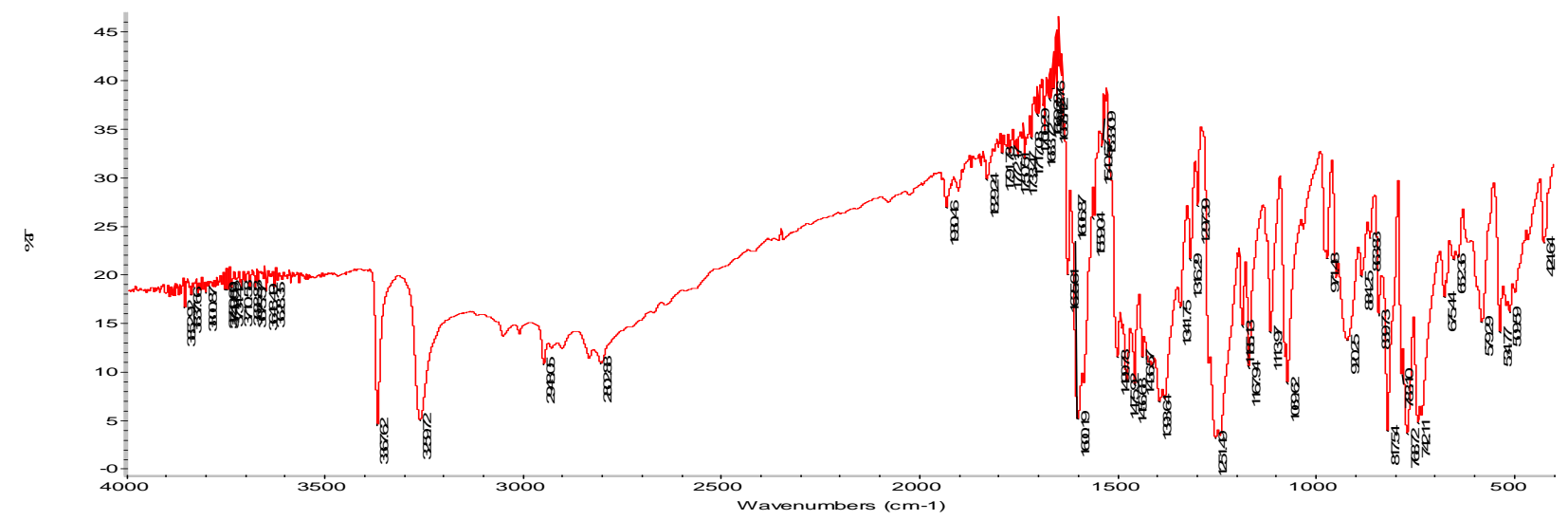

(a)

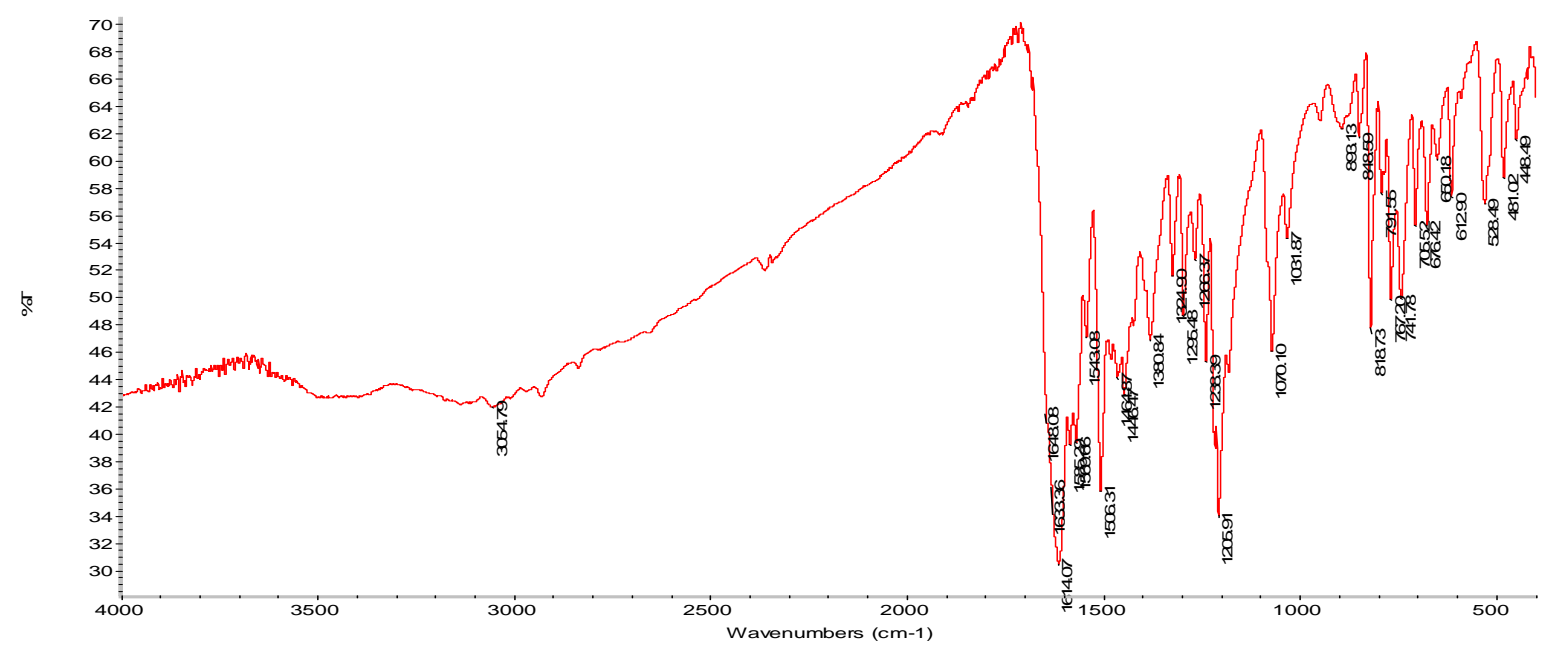

(b) 


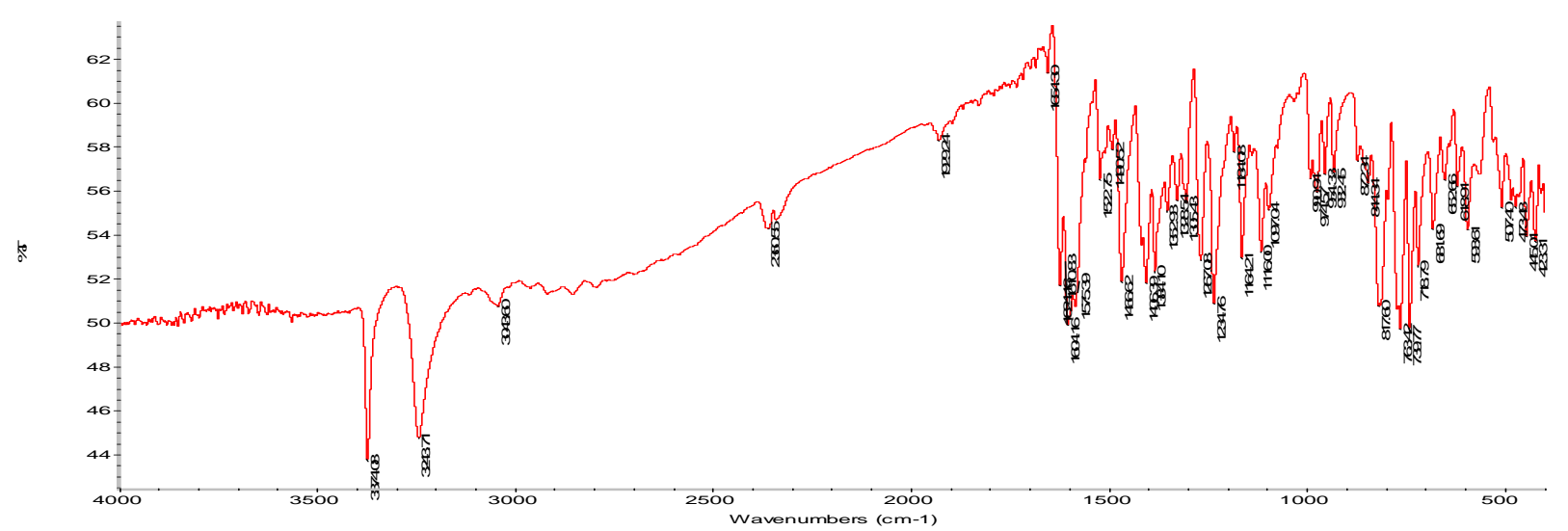

(c)

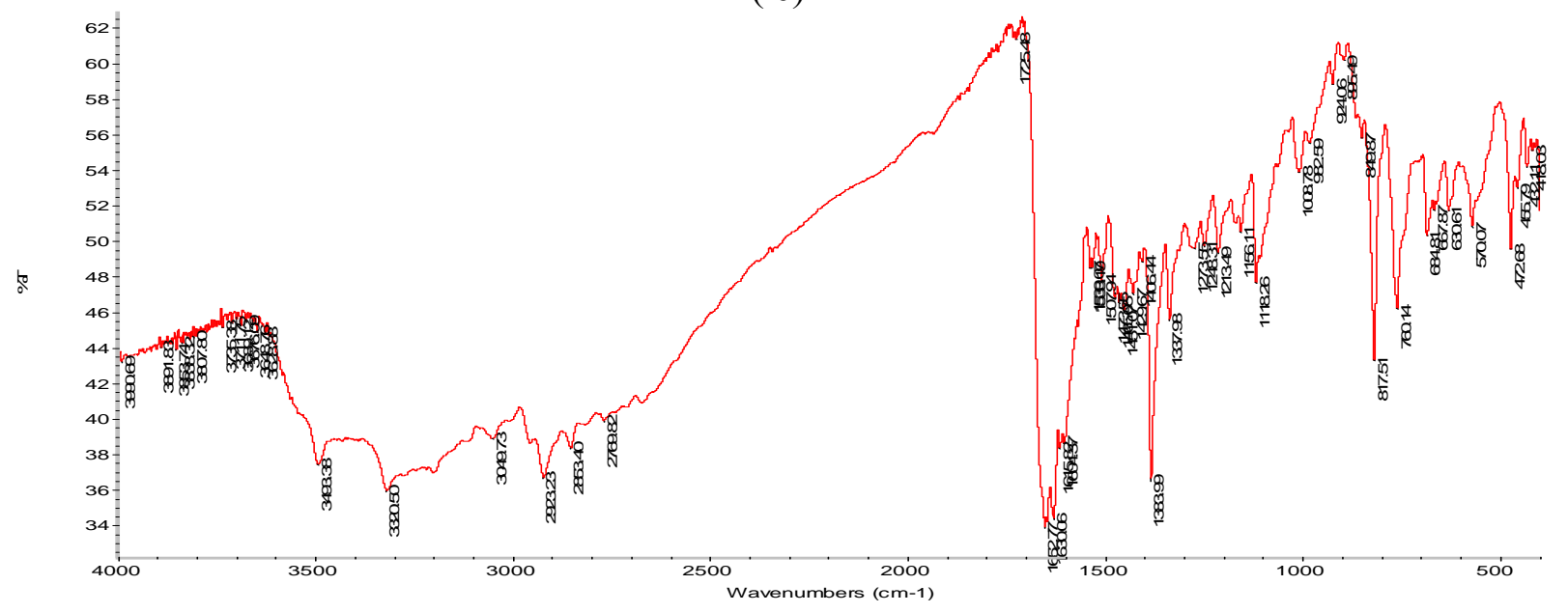

(d)

Fig 1:The I.R spectrum of (a) $\mathrm{H}_{2} \mathrm{~L}^{1}(\mathrm{~b})\left[\mathrm{NiL}^{1}\right]$ (c) $\mathrm{H}_{2} \mathrm{~L}^{2}$ and(d)[ $\left.\mathrm{NiL}^{2}\right]$

\section{Electronic Spectra and Magnetism}

The magnetic moments and electronic spectral data at $25^{\circ} \mathrm{C}$ of the ligands and theircomplexes are listed in (Table 3). The electronic spectra of the ligands $\mathrm{H}_{2} \mathrm{~L}^{1}$ and $\mathrm{H}_{2} \mathrm{~L}^{2}$ in $\mathrm{DMF}$ solution show the aromatic intense bands at (34233and 35000) $\mathrm{cm}^{-1}$ attributed to $\pi \rightarrow \pi^{*}$ transitionand at (32333 and 33232) $\mathrm{cm}^{-1}$ due to the $\mathrm{n} \rightarrow \pi^{*}$ transition of non-bonding electrons present on the nitrogen of the azomethine group. These transitions are also found in spectra of complexes but they are shifted, confirming the coordination of ligands to metal ions (Zeyrek et al., 2005). The new bands in spectra of all complexes at the range (27027-30027) $\mathrm{cm}^{-1}$ may be associated with the charge transfer transition(Khandar et al., 2011). The magnetic moment values of Co(II) complexes $(1,8)$ are found to be $(2.89,2.15) B . M$ respectively indicating square-planar (Bailar andVraban,1973). Their electronic spectra show absorption band at $(16528,16728) \mathrm{cm}^{-1}$ respectively, attributed to the ${ }^{2} \mathrm{~A}_{1} \mathrm{~g} \rightarrow{ }^{2} \mathrm{E}^{\prime} \mathrm{g}$ transition, indicating a square-planer geometry for $\mathrm{Co}$ (II) complexes(Ahmed et al., 2009), while the magnetic moment of Co(II) complexes $(5,12)$ equal( 4.91 , 4.96) B.M indicating octahedral geometry (Pathan et al., 2012) and the electronic spectra of these complexes showed d-d transitions at $(15151,15251) \mathrm{cm}^{-1},(20000$ and 20618$) \mathrm{cm}^{-1}$ assignable to ${ }^{4} \mathrm{~T}_{1} \mathrm{~g}(\mathrm{~F}) \rightarrow{ }^{4} \mathrm{~A}_{2} \mathrm{p}(\mathrm{F})$ and ${ }^{4} \mathrm{~T}_{1} \mathrm{~g}(\mathrm{~F}) \rightarrow{ }^{4} \mathrm{~T}_{1} \mathrm{~g}(\mathrm{p})$ respectively indicating octahedral geometry around $\mathrm{Co}(\mathrm{II})$ ions (Matrtell, 1971).

The Ni(II) complexes $(2,9)$ are diamagnetic moiety because its magnetic moment is almost zero. Therefore, the Schiff bases ligands coordinate to Ni(II)ion as tetradentate chelating agent with a square-planar environment(Raman et al., 2007). The electronic spectra of these complexes show absorption bands at (17666and17680) and (23529 and 23727) $\mathrm{cm}^{-1}$ attributed to the $\mathrm{A}_{1} \mathrm{~g} \rightarrow{ }^{1} \mathrm{~A}_{2} \mathrm{~g}$ and ${ }^{1} \mathrm{~A}_{1} \mathrm{~g} \rightarrow{ }^{1} \mathrm{~B}_{1} \mathrm{~g}$ transitionrespectively. This shows that $\mathrm{Ni}(\mathrm{II})$ complexes have a square-planer geometry (Fierro et al., 2011). For Ni(II) complexes $(6,13)$ the magnetic moment values are 
$(2.83,3.15)$ B.M, indicating the octahedral configuration with two unpaired electrons (Al-Daher and Mohammed, 2018) and The electronic spectra of those complexes show bands at $(17857,18518)$ $\mathrm{cm}^{-1}$ and $(23419,23529) \mathrm{cm}^{-1}$ assignable to ${ }^{3} \mathrm{~A}_{2} \mathrm{~g}(\mathrm{~F}) \rightarrow{ }^{3} \mathrm{~T}_{1} \mathrm{~g}(\mathrm{~F})$ and ${ }^{3} \mathrm{~A}_{2} \mathrm{~g}(\mathrm{~F}) \rightarrow{ }^{3} \mathrm{~T}_{1} \mathrm{~g}(\mathrm{P})$; these bands are characteristicsof octahedral geometry (Singh et al., 1989).

The obtained magnetic moment values for $\mathrm{Cu}$ (II) complexes (310) are (1.80 and 1.82) B.M indicating square-planar system (Lever, 1968). The electronic spectra of $\mathrm{Cu}$ (II) complexes showed weak bands at (17600 and 17857) and (24810 and 24814) $\mathrm{cm}^{-1}$ is attributed to the ${ }^{2} \mathrm{~B}_{1} \mathrm{~g} \rightarrow{ }^{2} \mathrm{~A}_{1} \mathrm{~g}$ and ${ }^{2} \mathrm{~B}_{1} \mathrm{~g} \rightarrow{ }^{2} \mathrm{Eg}$ transition respectively which is comparable with complexes having square-planar structure (Lever et al., 1984). The obtained magnetic values of $\mathrm{Cu}$ (II) complexes $(7,14)$ at $(1.94$ ,1.98)B.M indicating octahedral system (Pathan et al., 2012). The electronic spectra of $\mathrm{Cu}$ (II)complexes showed one broad band at $(13888,14705) \mathrm{cm}^{-1}$ which might be assigned to $^{2} \mathrm{Eg} \rightarrow{ }^{2} \mathrm{~T}_{2} \mathrm{~g}$ transition suggesting an octahedral (Cotton et al.,1999) geometry around $\mathrm{Cu}(\mathrm{II})$ in these complexes.

The electronic spectrum of $\mathrm{Zn}$ (II) complexes (4,11) show only a band at (28277-29250) $\mathrm{cm}^{1}$ attributed to the ligands charge transfer transition. The $\mathrm{Zn}$ (II) complexes are expected to be diamagnetic and their geometry is most probably similar to the $\mathrm{Co}(\mathrm{II}), \mathrm{Ni}$ (II) and $\mathrm{Cu}(\mathrm{II})$ complexes, depending on the data of other measurements namely metal content and I.R spectra(Geary 1971).

\section{${ }^{1}$ H-NMR-Spectra of ligands.}

The ${ }^{1} \mathrm{H}-\mathrm{NMR}$.spectra of free ligand at room temperature in DMSO-d ${ }^{6}$ shows the following singles(Shelke et al., 2012; Wahba et al., 2017).

ForH $_{2} \mathrm{~L}^{1}: \delta=3.25\left(3 \mathrm{H},-\mathrm{CH}_{3}\right), \delta=3.25\left(3 \mathrm{H}-\mathrm{OCH}_{3}\right), \delta=5.64 \quad(2 \mathrm{H}$, phenolic $), \delta=(6.46-7.25)(13 \mathrm{H}$, aromatic), $\delta=8.88(2 \mathrm{H}$, azomethine).

ForH $_{2} \mathrm{~L}^{2}: \delta=10.02(2 \mathrm{H}$, phenolic $\left.), \delta=((6.26-7.34)),(7.737 .87)\right)(16 \mathrm{H}$, Aromatic $), \delta=3.25 \quad\left(3 \mathrm{H}, \mathrm{CH}_{3}\right)$, $\delta=8.81,8.66(2 \mathrm{H}$,azomethin). The spectra of ligands have been shown Fig(2).

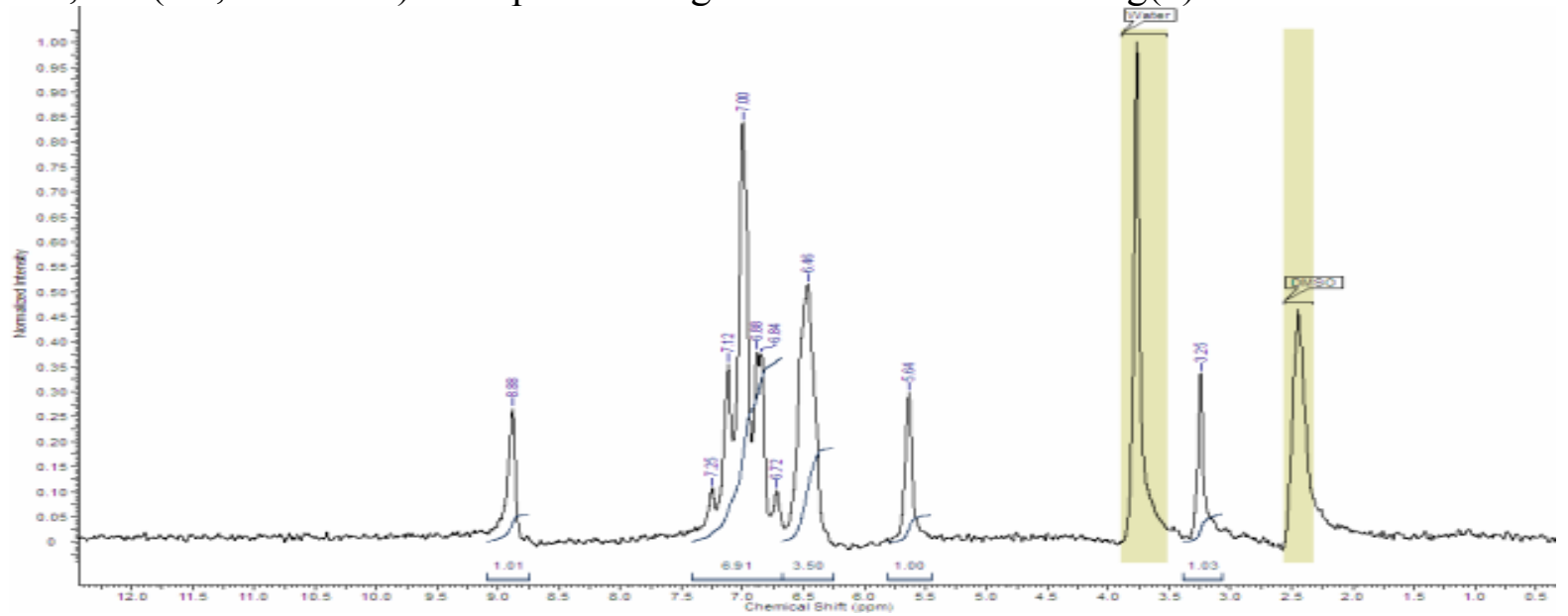

(a)

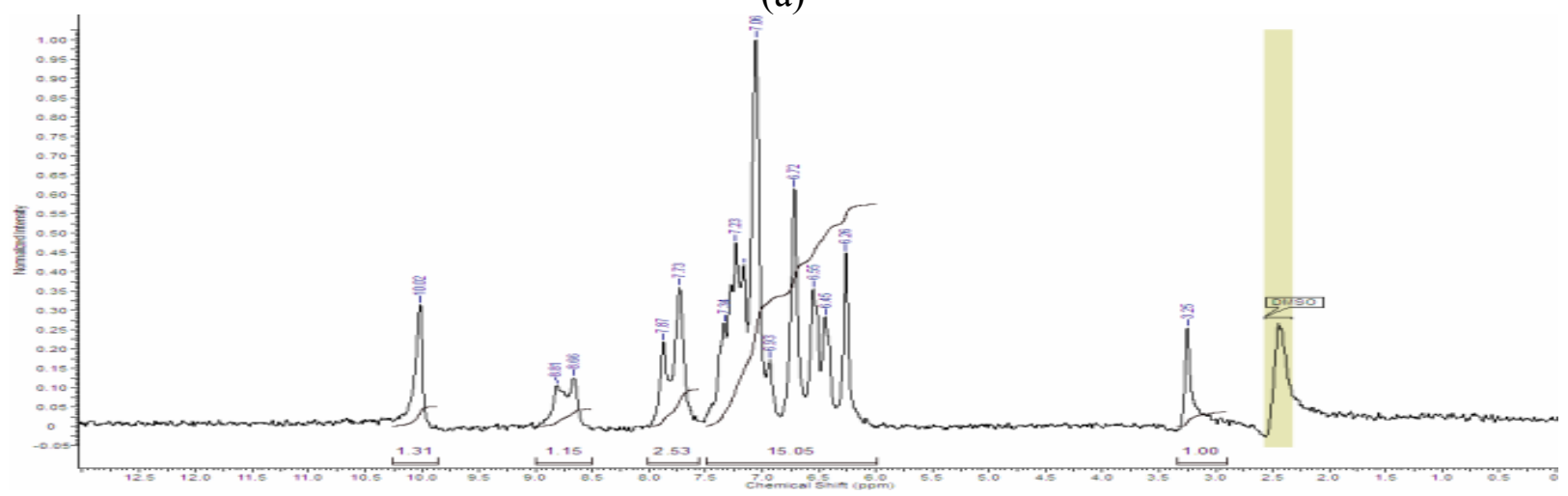

(b)

Fig 2: ${ }^{1} \mathrm{HNMR}$ of(a) $\mathrm{H}_{2} \mathrm{~L}^{1}$ and (b) $\mathrm{H}_{2} \mathrm{~L}^{2}$ 


\section{Antibacterial Activity:}

The tested compounds were screened in vitro for their antibacterial activity against bacteria gram negativebacteria(Salmonella typhi and Escherichia coli). The anti- bacterial results are given in (Table 4), Compared with those of the standard drug ceftriaxone. The results evidently show that metal(II) complexes have been shown to be more effective than the free ligands. Theactivity order of the synthesized compound against Salmonella styphi of synthesized compounds is as follows $\left[\mathrm{NiL}^{2}(\mathrm{py})_{2}\right]>\left[\mathrm{CoL}^{1}\right]>\left[\mathrm{NiL}^{2}\right]>\left[\mathrm{NiL}^{1}(\mathrm{py})_{2}\right]>\left[\mathrm{CoL}^{1}(\mathrm{py})_{2}\right]$ while the antibacterial activity of ligands and other complexes =zero. The activity order of the synthesized compound against Escherichia coli $\left[\mathrm{NiL}^{1}\right]=\left[\mathrm{NiL}^{2}\right]>\left[\mathrm{NiL}^{1}(\mathrm{py})_{2}\right]>\left[\mathrm{NiL}^{2}(\mathrm{py})_{2}\right]>\left[\mathrm{CoL}^{1}(\mathrm{py})_{2}\right]$ while the antibacterial activity of ligands and other complexes = zero ligands higher antibacterial activity of some metal complexes than the free Schiff base ligands that can be explained by chelation of Schiff base with metal ions (Joseyphus and Nair, 2008) as chelates display both polar and nonpolar properties; this makes them suitable for permeation into cells and tissues.

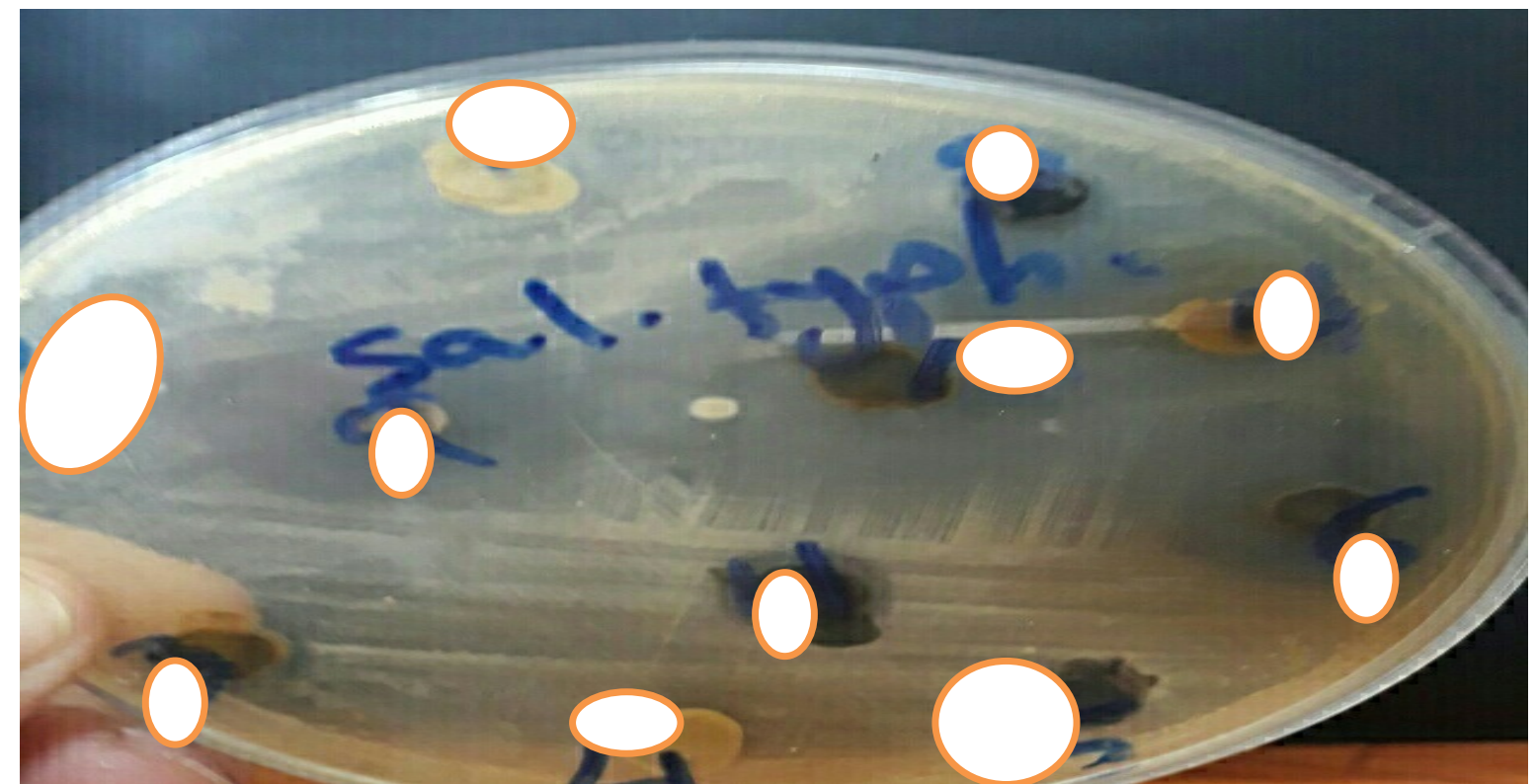

(a) (Salmonila taphi)

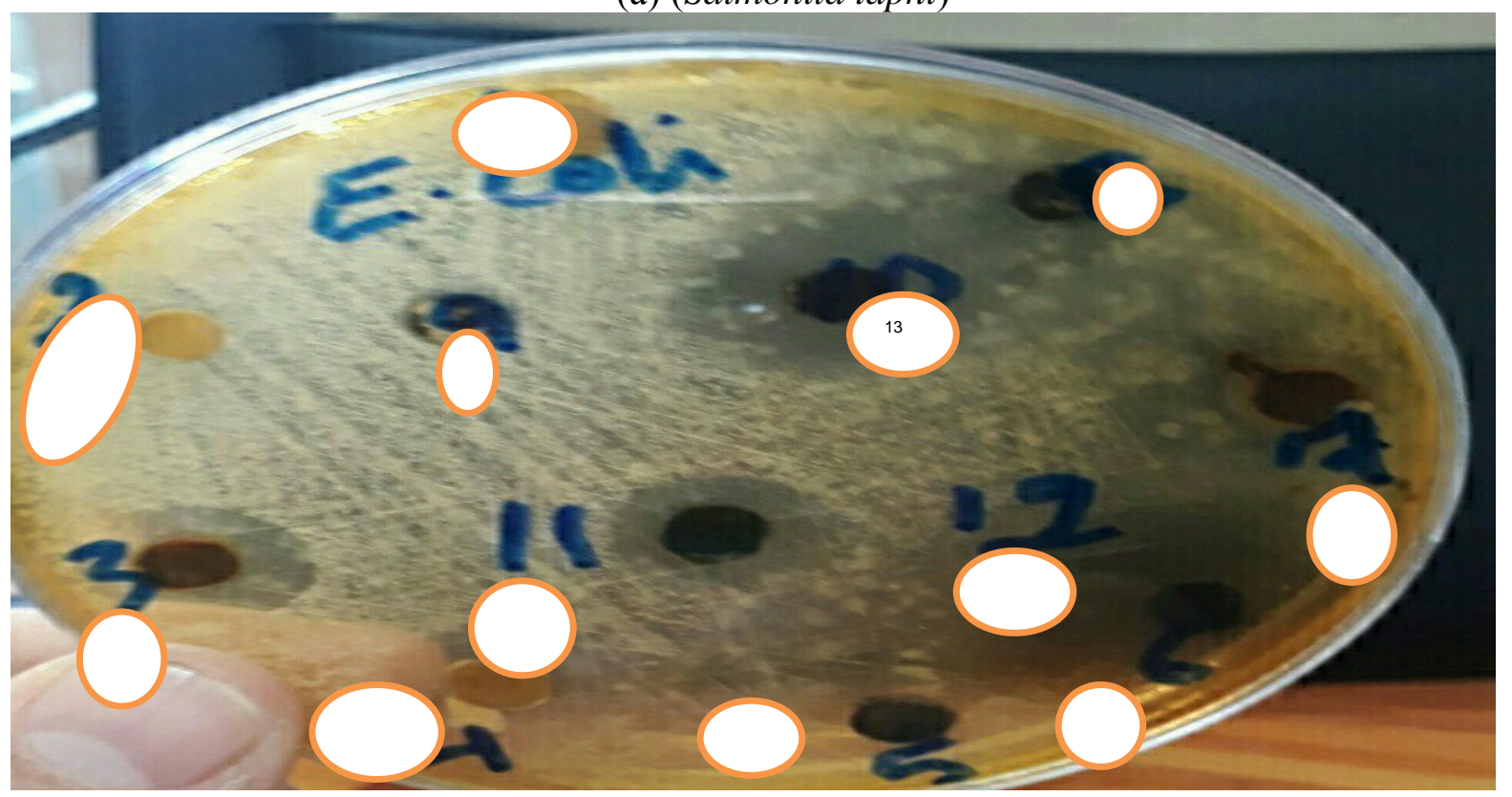

(b)(Escherichia coli)

Fig 3 : Antibacterial Bacterial Activity of ligands and complexes for (a) Salmonella typhi,(b) Escherichia coli 


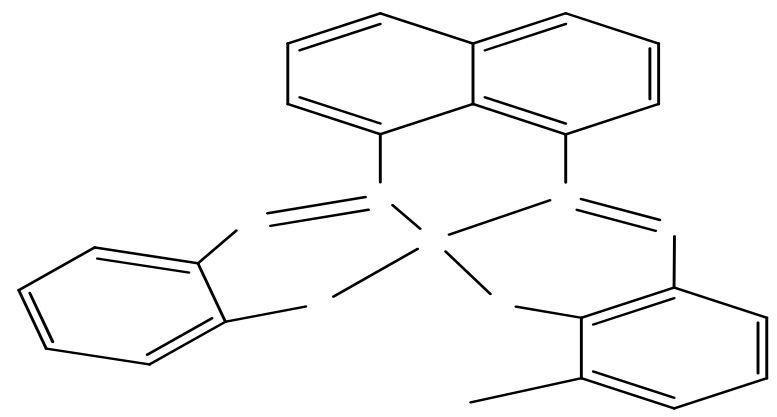

$\left[\mathrm{ML}^{1}\right]$

Complexes $(1,2,3,4)$

$\mathrm{M}=\mathrm{Co}(\mathrm{II}), \mathrm{Ni}(\mathrm{II}), \mathrm{Cu}(\mathrm{II}), \mathrm{Zn}(\mathrm{II})$

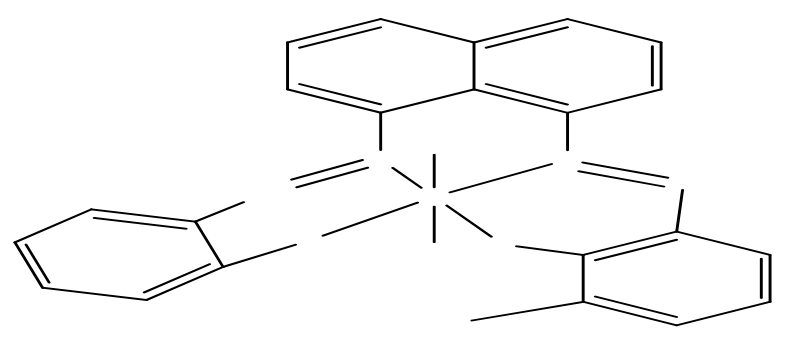

$N$

$\left[\mathrm{ML}^{1}(\mathrm{py})_{2}\right]$

Complexes $(5,6,7)$

$\mathrm{M}=\mathrm{Co}(\mathrm{II}), \mathrm{Ni}(\mathrm{II}), \mathrm{Cu}(\mathrm{II})$

$\mathrm{H}_{3} \mathrm{CO}$

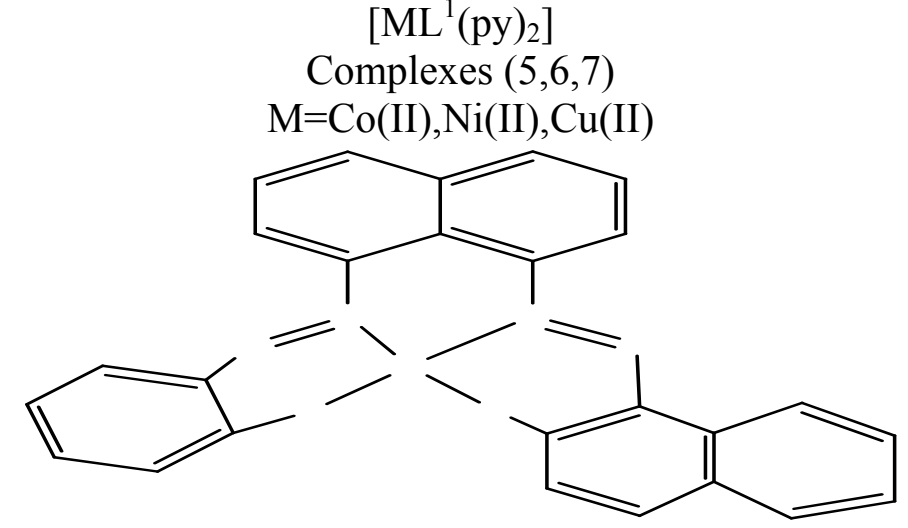

$\mathrm{O}$

$\left[\mathrm{ML}^{2}\right]$

Complexes $(8,9,10,11)$

$\mathrm{M}=\mathrm{Co}(\mathrm{II}), \mathrm{Ni}(\mathrm{II}), \mathrm{Cu}(\mathrm{II}), \mathrm{Zn}(\mathrm{II})$
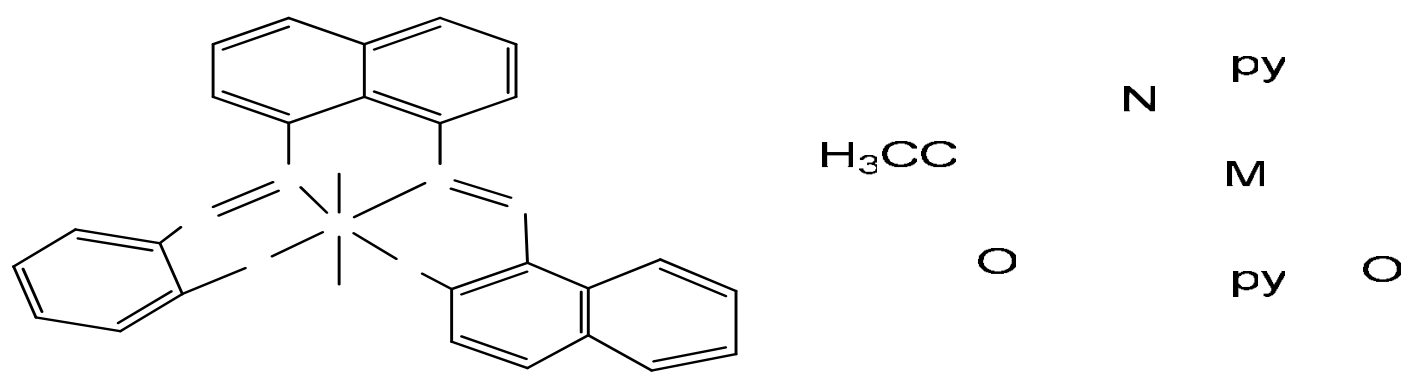

$\left[\mathrm{ML}^{2}(\mathrm{py})_{2}\right]$ 
Synthesis, Characterization and Antibacterial..........

Table 1: Some physical properties and analysis of the ligands and their complexes

\begin{tabular}{|c|c|c|c|c|c|c|c|c|}
\hline \multirow{2}{*}{ NO. } & \multirow[t]{2}{*}{ Complexes } & \multirow[t]{2}{*}{ Color } & \multirow[t]{2}{*}{ m.p $\left(\mathbf{C}^{0}\right)$} & \multicolumn{3}{|c|}{ Analysis calc.(found)\% } & \multirow{2}{*}{$\begin{array}{l}\text { M\% Calc. } \\
\text { (found) }\end{array}$} & \multirow{2}{*}{$\underset{\left.\mathrm{cm}^{2} \mathrm{~mol}^{-1}\right)}{\Lambda \mathrm{m}\left(\mathrm{ohm}^{-1}\right.}$} \\
\hline & & & & $\% \mathrm{C}$ & $\% \mathrm{H}$ & $\% \mathrm{~N}$ & & \\
\hline $\mathrm{H}_{2} \mathrm{~L}^{\mathrm{I}}$ & $\mathrm{C}_{26} \mathrm{H}_{22} \mathrm{~N}_{2} \mathrm{O}_{3}$ & Milky & 190-191 & $\begin{array}{c}76.07 \\
(76.03)\end{array}$ & $\begin{array}{c}5.40 \\
(5.20)\end{array}$ & $\begin{array}{c}6.82 \\
(6.50)\end{array}$ & ----- & $\begin{array}{c}--- \\
\end{array}$ \\
\hline 1 & {$\left[\mathrm{Co} \mathrm{L}^{1}\right]$} & $\begin{array}{l}\text { Dark } \\
\text { green }\end{array}$ & $>300 \mathrm{~d}$ & --- & ---- & ---- & $\begin{array}{c}12.60 \\
(12.50)\end{array}$ & 5.19 \\
\hline 2 & {$\left[\mathrm{Ni} \mathrm{L}^{1}\right]$} & Orange & $238 \mathrm{~d}$ & $\begin{array}{c}66.84 \\
(66.40)\end{array}$ & $\begin{array}{c}4.31 \\
(4.10)\end{array}$ & $5.99(4.45)$ & $\begin{array}{c}12.56 \\
(12.30)\end{array}$ & 7.00 \\
\hline 3 & {$\left[\mathrm{Cu} \mathrm{L}^{1}\right]$} & $\begin{array}{c}\text { Drack } \\
\text { grey }\end{array}$ & $>300 \mathrm{~d}$ & ---- & ---- & ----- & $13.46(13.10)$ & 16.88 \\
\hline 4 & {$\left[\mathrm{Zn} \mathrm{L}^{1}\right]$} & Orange & $219 d$ & ---- & ---- & ---- & $13.79(13.52)$ & 4.47 \\
\hline 5 & {$\left[\mathrm{Co} \mathrm{L}^{1}(\mathrm{py})_{2}\right]$} & $\begin{array}{l}\text { Drack } \\
\text { brown }\end{array}$ & $257 d$ & ---- & ------- & ----- & $9.42(9.28)$ & 11.55 \\
\hline 6 & {$\left[\mathrm{NiL}^{1}(\mathrm{py})_{2}\right]$} & $\begin{array}{l}\text { Green- } \\
\text { Yellow }\end{array}$ & $293 \mathrm{~d}$ & ---- & ----- & ---- & $9.38(9.15)$ & 5.05 \\
\hline 7 & {$\left[\mathrm{Cu} \mathrm{L}^{1}(\mathrm{py})_{2}\right]$} & $\begin{array}{l}\text { Drack } \\
\text { grey }\end{array}$ & $>300 \mathrm{~d}$ & $\begin{array}{c}68.61 \\
(68.30) \\
\end{array}$ & $\begin{array}{c}4.79 \\
(4.36)\end{array}$ & $8.89(8.72)$ & $10.08(10.01)$ & 10.41 \\
\hline $\mathrm{H}_{2} \mathrm{~L}^{2}$ & $\mathrm{C}_{29} \mathrm{H}_{22} \mathrm{~N}_{2} \mathrm{O}_{2}$ & Off white & $182-184$ & $\begin{array}{c}80.90 \\
(80.70)\end{array}$ & $\begin{array}{c}5.15 \\
(5.02)\end{array}$ & $6.50(6.32)$ & $\begin{array}{ll}----- \\
\end{array}$ & - \\
\hline 8 & {$\left[\mathrm{Co} \mathrm{L}^{2}\right]$} & Orange & $228 \mathrm{~d}$ & $\begin{array}{c}71.46 \\
(71.30) \\
\end{array}$ & $\begin{array}{c}4.13 \\
(4.05)\end{array}$ & $5.74(5.30)$ & $12.09(11.98)$ & 10.55 \\
\hline 9 & {$\left[\mathrm{Ni} \mathrm{L}^{2}\right]$} & Black & $167 d$ & ----- & ---- & ----- & $12.05(12.00)$ & 26.18 \\
\hline 10 & {$\left[\mathrm{Cu} \mathrm{L}^{2}\right]$} & $\begin{array}{l}\begin{array}{l}\text { Drack } \\
\text { grey }\end{array} \\
\end{array}$ & $>300 \mathrm{~d}$ & ----- & $\begin{array}{l}----- \\
\end{array}$ & $\begin{array}{ll}----- \\
\end{array}$ & $12.91(12.42)$ & 19.89 \\
\hline 11 & {$\left[\mathrm{Zn} \mathrm{L}^{2}\right]$} & $\begin{array}{c}\text { Drack } \\
\text { orange }\end{array}$ & $184-186$ & ----- & $\begin{array}{l}---- \\
\end{array}$ & $\begin{array}{l}---- \\
\end{array}$ & $13.23(13.08)$ & 0.4 \\
\hline 12 & {$\left[\mathrm{Co} \mathrm{L}^{2}(\mathrm{py})_{2}\right]$} & $\begin{array}{c}\text { Medium } \\
\text { brown }\end{array}$ & $144 \mathrm{~d}$ & $\begin{array}{c}72.55 \\
(72.50)\end{array}$ & $\begin{array}{c}4.68 \\
(4.51)\end{array}$ & $8.67(8.34)$ & $9.12(9.02)$ & 5.57 \\
\hline 13 & {$\left[\mathrm{Ni} \mathrm{L}{ }^{2}(\mathrm{Py})_{2}\right]$} & Yellow & $234 d$ & ---- & ---- & ----- & $9.09(8.99)$ & 24.96 \\
\hline 14 & {$\left[\mathrm{Cu} \mathrm{L}^{2}(\mathrm{py})_{2}\right]$} & $\begin{array}{l}\text { Drack } \\
\text { Green }\end{array}$ & $246 d$ & ------ & ------ & ----- & $9.77(9.50)$ & 9.09 \\
\hline
\end{tabular}

Table 2: Characteristic Infrared spectral data of the ligands and their complexes

\begin{tabular}{|c|c|c|c|c|c|c|c|}
\hline \multirow{2}{*}{ NO. } & \multirow{2}{*}{ Complexes } & \multicolumn{6}{|c|}{ IR spectral bands (cm-1) } \\
\hline & & v $(\mathrm{C}=\mathrm{N}$ imin $)$ & v (C-O ) phenol & $\mathrm{v}(\mathrm{O}-\mathrm{H})$ & v (M-N) & v(M-O) & $\begin{array}{c}\text { v } \mathrm{C}= \\
\text { Npyridine ring }\end{array}$ \\
\hline $\mathrm{H}_{2} \mathrm{~L}^{\mathrm{I}}$ & $\mathrm{C}_{26} \mathrm{H}_{22} \mathrm{~N}_{2} \mathrm{O}_{3}$ & $(1606,1625) \mathrm{s}$ & $(1185,1251) \mathrm{s}$ & $(3259,3367) \mathrm{s}$ & $\begin{array}{ll}--- \\
\end{array}$ & $\begin{array}{ll}--- \\
\end{array}$ & $\begin{array}{ll}---- \\
\end{array}$ \\
\hline 1 & {$\left[\mathrm{Co} \mathrm{L}^{1}\right]$} & $(1618,1635) \mathrm{s}$ & $(1247,1293) \mathrm{m}$ & ---- & $473 \mathrm{~m}$ & $527 \mathrm{~s}$ & ----- \\
\hline 2 & {$\left[\mathrm{Ni} \mathrm{L}{ }^{1}\right]$} & $(1633,1648) \mathrm{s}$ & $(1238,1266) \mathrm{s}$ & $\begin{array}{c}---- \\
-\cdots\end{array}$ & $481 \mathrm{w}$ & $528 \mathrm{~m}$ & $\begin{array}{ll}----- \\
-\end{array}$ \\
\hline 3 & {$\left[\mathrm{Cu} \mathrm{L}^{1}\right]$} & $(1616,1652) \mathrm{s}$ & $(1245,1256) \mathrm{s}$ & $\begin{array}{ll}---- \\
--1\end{array}$ & $458 \mathrm{w}$ & $520 \mathrm{~m}$ & ------ \\
\hline 4 & {$\left[\mathrm{Zn} \mathrm{L}^{1}\right]$} & $(1612,1654) \mathrm{s}$ & $(1240,1260) \mathrm{m}$ & $\begin{array}{l}----- \\
\end{array}$ & $478 \mathrm{w}$ & $520 \mathrm{~s}$ & $\begin{array}{ll}----- \\
\end{array}$ \\
\hline 5 & {$\left[\mathrm{Co} \mathrm{L}^{1}(\mathrm{py})_{2}\right]$} & $(1615,1666) \mathrm{s}$ & $(1194,1273) \mathrm{s}$ & ----- & $472 \mathrm{w}, 475 \mathrm{~m}$ & $575 \mathrm{w}$ & $1473 m$ \\
\hline 6 & {$\left[\mathrm{NiL}^{1}(\mathrm{py})_{2}\right]$} & $(1620,1635) \mathrm{s}$ & $(1248,1271) \mathrm{s}$ & $\begin{array}{ll}----- \\
\end{array}$ & $475 \mathrm{w}, 480 \mathrm{w}$ & $520 \mathrm{~m}$ & $1506 \mathrm{~s}$ \\
\hline 7 & {$\left[\mathrm{Cu} \mathrm{L}^{1}(\mathrm{py})_{2}\right]$} & $(1622,1658) \mathrm{s}$ & $(1250,1268) \mathrm{s}$ & -------- & $470 \mathrm{~m}, 475 \mathrm{w}$ & $530 \mathrm{w}$ & $1500 \mathrm{~s}$ \\
\hline $\mathrm{H}_{2} \mathrm{~L}^{2}$ & $\mathrm{C}_{29} \mathrm{H}_{22} \mathrm{~N}_{2} \mathrm{O}_{2}$ & $(1610,1624) \mathrm{s}$ & $(1234,1267) \mathrm{s}$ & $(3243,3374) \mathrm{s}$ & 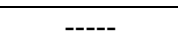 & $\begin{array}{ll}----- \\
\end{array}$ & ----- \\
\hline 8 & {$\left[\mathrm{Co} \mathrm{L}^{2}\right]$} & $(1615,1666) \mathrm{s}$ & $(1251,1275) \mathrm{s}$ & ------ & $480 \mathrm{w}$ & $516 \mathrm{~m}$ & ----- \\
\hline 9 & {$\left[\mathrm{Ni} \mathrm{L}^{2}\right]$} & $(1630,1652) \mathrm{s}$ & $(1248,1273) \mathrm{s}$ & ------- & $472 \mathrm{w}$ & $570 \mathrm{~m}$ & ----- \\
\hline 10 & {$\left[\mathrm{Cu} \mathrm{L}^{2}\right]$} & $(1628,1635) \mathrm{s}$ & $(1244,1274) \mathrm{s}$ & ------- & $472 \mathrm{w}$ & $529 \mathrm{~m}$ & ------ \\
\hline 11 & {$\left[\mathrm{Zn} \mathrm{L}^{2}\right]$} & $(1612,1630) \mathrm{s}$ & $(1248,1270) \mathrm{s}$ & ------ & $472 \mathrm{w}$ & $503 \mathrm{~m}$ & ----- \\
\hline 12 & {$\left[\mathrm{Co} \mathrm{L}^{2}(\mathrm{py})_{2}\right]$} & $(1616,1635) \mathrm{s}$ & $(1245,1271) \mathrm{s}$ & ------- & $450 \mathrm{w}, 472 \mathrm{~m}$ & $569 \mathrm{~m}$ & $1488 \mathrm{~m}$ \\
\hline 13 & {$\left[\mathrm{Ni} \mathrm{L}{ }^{2}(\mathrm{Py})_{2}\right]$} & $(1640,1655) \mathrm{s}$ & $(1255,1280) \mathrm{s}$ & ----- & $481 \mathrm{~m}, 475$ & $580 \mathrm{w}$ & $1500 \mathrm{~m}$ \\
\hline 14 & {$\left[\mathrm{Cu} \mathrm{L}^{2}(\mathrm{py})_{2}\right]$} & $(1630,1642) \mathrm{s}$ & $(1250,1286) \mathrm{s}$ & $\begin{array}{l}----- \\
\end{array}$ & $450 \mathrm{~m}, 480 \mathrm{~m}$ & $560 \mathrm{~m}$ & $1498 w$ \\
\hline
\end{tabular}


Table 3 : Magnetic moments and the electronic spectral data of the ligands and their complexes

\begin{tabular}{|c|c|c|c|c|c|}
\hline No. & Complexes & $\mu_{\text {eff }}$ (B.M) & assignment & Band maxima $\lambda\left(\mathrm{cm}^{-1}\right)$ & Strut. \\
\hline $\mathrm{H}_{2} \mathrm{~L}^{1}$ & $\mathrm{C}_{26} \mathrm{H}_{22} \mathrm{~N}_{2} \mathrm{O}_{3}$ & ---- & $\mathrm{n} \rightarrow \pi^{*}, \pi \rightarrow \pi^{*}$ & 32333,34233 & ---- \\
\hline 1 & {$\left[\mathrm{CoL}^{1}\right]$} & 2.89 & ${ }^{2} \mathrm{~A}_{1} \mathrm{~g} \rightarrow{ }^{2} \mathrm{E}^{\prime} \mathrm{g}, \mathrm{C} . \mathrm{T}$ & 16528,27397 & S.q \\
\hline 2 & {$\left[\mathrm{NiL}^{1}\right]$} & Diamagnetic & ${ }^{1} \mathrm{~A}_{1} \mathrm{~g} \rightarrow{ }^{1} \mathrm{~A}_{2} \mathrm{~g},{ }^{1} \mathrm{~A}_{1} \mathrm{~g} \rightarrow{ }^{1} \mathrm{~B}_{1} \mathrm{~g}, \mathrm{C} . \mathrm{T}$ & $17680,23529,28857$ & S.q \\
\hline 3 & {$\left[\mathrm{CuL}^{1}\right]$} & 1.80 & ${ }^{2} \mathrm{~B}_{1} \mathrm{~g} \rightarrow{ }^{2} \mathrm{~A}_{1} \mathrm{~g},{ }^{2} \mathrm{~B}_{1} \mathrm{~g} \rightarrow{ }^{2} \mathrm{Eg}, \mathrm{C} . \mathrm{T}$ & $17857,24810,27777$ & S.q \\
\hline 4 & {$\left[\mathrm{Zn} \mathrm{L}^{1}\right]$} & Diamagnetic & C.T & 29250 & S.q \\
\hline 5 & {$\left[\mathrm{Co} \mathrm{L}^{1}(\mathrm{py})_{2}\right]$} & 4.69 & ${ }^{4} \mathrm{~T}_{1} \mathrm{~g}(\mathrm{~F}) \rightarrow{ }^{4} \mathrm{~A}_{2} \mathrm{~g}(\mathrm{~F}){ }^{4} \mathrm{~T}_{1} \mathrm{~g}(\mathrm{~F}) \rightarrow{ }^{4} \mathrm{~T}_{1} \mathrm{~g}(\mathrm{p})$ & $15251,20618,27777$ & oct \\
\hline 6 & {$\left[\mathrm{NiL}^{1}(\mathrm{py})_{2}\right]$} & 3.15 & ${ }^{3} \mathrm{~A}_{2} \mathrm{~g}(\mathrm{~F}) \rightarrow{ }^{3} \mathrm{~T}_{1} \mathrm{~g}(\mathrm{~F}),{ }^{3} \mathrm{~A}_{2} \mathrm{~g} \rightarrow{ }^{3} \mathrm{~T}_{1} \mathrm{~g}(\mathrm{p})$ & $17857,23419,30027$ & oct \\
\hline 7 & {$\left[\mathrm{Cu} \mathrm{L}^{1}(\mathrm{py})_{2}\right]$} & 1.98 & ${ }^{2} \mathrm{Eg} \rightarrow{ }^{2} \mathrm{~T}_{2} \mathrm{~g}$ & 14705,27777 & oct \\
\hline $\mathrm{H}_{2} \mathrm{~L}^{2}$ & $\mathrm{C}_{29} \mathrm{H}_{22} \mathrm{~N}_{2} \mathrm{O}_{2}$ & ---- & $\mathrm{n} \rightarrow \pi^{*}, \pi \rightarrow \pi^{*}$ & 33232,35000 & ---- \\
\hline 8 & {$\left[\mathrm{Co} \mathrm{L}^{2}\right]$} & 2.15 & ${ }^{2} \mathrm{~A}_{1} \mathrm{~g} \rightarrow{ }^{2} \mathrm{E}^{\prime} \mathrm{g}, \mathrm{C} . \mathrm{T}$ & 16728,28345 & S.q \\
\hline 9 & {$\left[\mathrm{NiL}^{2}\right]$} & Diamagnetic & ${ }^{1} \mathrm{~A}_{1} \mathrm{~g} \rightarrow{ }^{1} \mathrm{~A}_{2} \mathrm{~g},{ }^{1} \mathrm{~A}_{1} \mathrm{~g} \rightarrow{ }^{1} \mathrm{~B}_{1} \mathrm{~g}, \mathrm{C}, \mathrm{T}$ & $17666,23727,27777$ & S.q \\
\hline 10 & {$\left[\mathrm{Cu} \mathrm{L}^{2}\right]$} & 1.82 & ${ }^{2} \mathrm{~B}_{1} \mathrm{~g} \rightarrow{ }^{2} \mathrm{~A}_{1} \mathrm{~g},{ }^{2} \mathrm{~B}_{1} \mathrm{~g} \rightarrow{ }^{2} \mathrm{Eg}, \mathrm{C} . \mathrm{T}$ & $17600,24814,29500$ & S.q \\
\hline 11 & {$\left[\mathrm{Zn} \mathrm{L}^{2}\right]$} & Diamagnetic & C.T & 28277 & S.q \\
\hline 12 & {$\left[\mathrm{Co} \mathrm{L}^{2}(\mathrm{py})_{2}\right]$} & 4.91 & ${ }^{4} \mathrm{~T}_{1} \mathrm{~g}(\mathrm{~F}) \rightarrow{ }^{4} \mathrm{~A}_{2} \mathrm{~g}(\mathrm{~F}){ }^{4} \mathrm{~T}_{1} \mathrm{~g}(\mathrm{~F}) \rightarrow{ }^{4} \mathrm{~T}_{1} \mathrm{~g}(\mathrm{p})$ & $15151,20000,27777$ & oct \\
\hline 13 & {$\left[\mathrm{Ni} \mathrm{L}^{2}(\mathrm{py})_{2}\right]$} & 2.83 & ${ }^{3} \mathrm{~A}_{2} \mathrm{~g}(\mathrm{~F}) \rightarrow{ }^{3} \mathrm{~T}_{1} \mathrm{~g}(\mathrm{~F}),{ }^{3} \mathrm{~A}_{2} \mathrm{~g} \rightarrow{ }^{3} \mathrm{~T}_{1} \mathrm{~g}(\mathrm{p})$ & $18518,23419,29221$ & oct \\
\hline 14 & {$\left[\mathrm{Cu} \mathrm{L}^{2}(\mathrm{py})_{2}\right]$} & 1.94 & ${ }^{2} \mathrm{Eg} \rightarrow{ }^{2} \mathrm{~T}_{2} \mathrm{~g}$ & 13888,27027 & oct \\
\hline
\end{tabular}

Table 4: The antibacterial activities of Schiff base and their complexes

\begin{tabular}{|c|c|c|}
\hline complexes & Salmonila styphi & Escherichia coli \\
\hline $\mathrm{H}_{2} \mathrm{~L}^{1}$ & 0 & 0 \\
\hline$\left[\mathrm{CoL}^{1}\right]$ & 22 & 0 \\
\hline$\left[\mathrm{NiL}^{1}\right]$ & 0 & 0 \\
\hline$\left[\mathrm{CuL}^{1}\right]$ & 0 & 0 \\
\hline$\left[\mathrm{ZnL}^{1}\right]$ & 0 & 13 \\
\hline$\left[\mathrm{CoL}^{1}(\mathrm{py})_{2}\right]$ & 15 & 20 \\
\hline$\left[\mathrm{NiL}^{1}(\mathrm{py})_{2}\right]$ & 17 & 0 \\
\hline$\left[\mathrm{CuL}^{1}(\mathrm{py})_{2}\right]$ & 0 & 0 \\
\hline $\mathrm{H}_{2} \mathrm{~L}^{2}$ & 0 & 0 \\
\hline$\left[\mathrm{CoL}^{2}\right]$ & 0 & 22 \\
\hline$\left[\mathrm{NiL}^{2}\right]$ & 18 & 0 \\
\hline$\left[\mathrm{CuL}^{2}\right]$ & 0 & 0 \\
\hline$\left[\mathrm{ZnL}^{2}\right]$ & 0 & 0 \\
\hline$\left[\mathrm{CoL}^{2}(\mathrm{py})_{2}\right]$ & 0 & 18 \\
\hline$\left[\mathrm{NiL}^{2}(\mathrm{py})_{2}\right]$ & 35 & 0 \\
\hline$\left[\mathrm{CuL}^{2}(\mathrm{py})_{2}\right]$ & 0 & 0 \\
\hline Inhibition zone diameter(mm)(\%inhibition $)(6-10)(27-45 \% ; 10-14(45-64 \%) ; 14-18(62-82 \%) ; 18-22(82-100 \%)$
\end{tabular}

\section{CONCLUSION}

Unsymmetrical Schiff bases and their complexes were prepared and characterized by spectral and analytical data. The synthesized Schiff base acts as adibasic tetradentate ligand coordinated via phenolic oxygen and azomethine nitrogen atoms illustration Fig (4). Magnetic and electronic spectral studies reveal square-planar structure for[ML] complexes and octahedral structure for $\left[\mathrm{ML}^{\mathrm{n}}(\mathrm{py})_{2}\right]$ adducts and from the test of bacteria we found that Some complexes have high activity towards gram negativebacteria (Salmonella typhi and Escherichia coli). 


\section{REFERENCES}

AbuBakar, A.F.; Bahron, H.; Kassim, K.; Zain, M.M. (2011). Synthesis, characterization and neurotoxic effect of schiff bases ligands and their complexes. The Malaysian J. Analytical Sci., 15(1),93-100.

Ahmed, A.A.; Benguzzi, S.A.; Agoob, A.O. (2009). Synthesis and characterization of some $\mathrm{N}_{2} \mathrm{O}_{2}$ schiff bases and their metal complexes. Rasyan. J. Chem., 2(2),271-275.

Al-Daher, A.G.M.; Mohammed, A.H. (2018). Preparation, characterization and study of Ethyl Pyruvate Aroyl Hydrazone Metal complexes. Raf.J.Sci., 27(3),100-112.

Al-Kattan, W.T.; Al-Niaa, E.M. (2014). Synthesis and characterization of Mn(II),Co(II),Ni(II), and $\mathrm{Cu}(\mathrm{II})$ Complexes with New Schiff Base Derived From Isophthalaldehyde and 2-amino-5nitropyridine. Raf. J. Sci., 25(2),67-75.

Arhana, P.E.; Dosanto, M.P.; Romera, S.; Docal, E.R. (2007). Synthesis, charcterization, and spectroscopic studies of tetradentate Schiff Base Chromium(III) complexes. Polyhedron. 26(7), 1373-1382.

Attari, M.H.; Mubarak, M.S.; Khalili, F.L. (1997). Preparationand characterization of some tetradentate schiff bases and their complexes with $\mathrm{Co}(\mathrm{II}), \mathrm{Ni}(\mathrm{II})$ and $\mathrm{Cu}(\mathrm{II})$. Synth. Ract. Inorg. Met Org. Nano-Met Chem., 27(1), 1-16.

Bailar, J.C.; Vraban, J.R. (1973)."Comprehensive Inorganic Chemistry". $1^{\text {st }}$.ed., Pergamon Press, Oxford.

Bauer, A.W.; Kirby, W.N.N.; Sherris, J.C.; Turck, M.(1966). Antibiotic Suceptipilty testing by standardized Single. Dsik Method Am. J. Clin. Pathol. 45, 493-496.

Bhagat, T.M.; Swamy, D.K.; Deshpande, M.N. (2012). Synthesis and characterization of transition metal complexes with newly synthesized benzothiazole. J. Chem. and Pharm. Research.,4, 100-104.

Gupta, K.C.; Sutar, A.K. (2007). Catalytic activities of schiff base transition metal complexes. Coordination Chem. Reviews. 252, 1420-1450.

Cotton, F.A.; Wilkinson, G.; Murillo, C.A.; Bochmann, M. (1999)."Advanced Inorganic Chemistry". $6^{\text {th }}$ ed., John-Wiley and Sons, New York. pp. 810-842.

Fierro, C.M.; Smith, P.D.; Horton, P.N.; Hursthouse, M.B.; Light, M.E. (2011). Synthesis and structures of Mono and Binuclear Nickel(II) Thiolate Complexes of adicompartmental Pesudo- Macrocycle with $\mathrm{N}($ Imine $) 2 \mathrm{~S}_{2}$ and $\mathrm{N}$ (oxime) $2 \mathrm{~S}_{2}$ metal-binding. Sites. Inorg Chem., Acta, 368, 257-262.

Geary, W.I. (1971). The use of conductivity measurements inorganic solvents for the characterization of coordination compounds. Coord. Chem. Rev.,7, 81-122.

Hancock, R.D.; Thornton, D.A. (1969). Crystal field aspects of vibrational spectra:1First-Row Transition Metal(III) B-Ketone Kates. J. Mol. Struct., 4, 361- 367.

Hegzy, W.H.; Gaafar, A.E-D.M. (2012). Synthesis, characterization and antibacterial activates of New $\mathrm{Pd}(\mathrm{II})$ and $\mathrm{Pt}(\mathrm{IV})$ complexes of some unsymmetrical tetradentate schiff bases. American Chem. Sci., J., 2(3),86-99.

Joel, C.; David, S.T.; Bennie, R.B.; Abraham, D.S.; Pillai, I.S.(2015). Binding studies of some novelmacrocyclic transition metal complexes towards CT-DNA via multispectroscopic techniques. J. Chem. and Pharmaceut. Resarch,7(5),1159-1176.

Joseyphus, R.S.; Nair, M.S. (2008). Antibacterial and antifungal studies on some schiff base complexes of Zinc(II). Mycobiology. 36, 93-97.

Jyaseelan, P.; Prasad, S.; Vedanayaki, S.; Rajavel, R.(2011). Synthesis Spectral characterization, electrochemical and antimicrobial activities of new binuclear schiff base metal complexes derived from 3,3'diaminobenzedine. Eur. J. Chem., 2(4),480.

Khandar, A.A.; Butcher, R.J.; Abedi, M.; Yazdi, S.A.H.; Akkurt, M.; Tahir, M.N.(2011). Synthesis characterization and crystal structures of di-three-coordinated Copper (I) macro cyclic schiff base complexes. Polyhedron, 30, 942-946. 
Lever, A.B.P.(1968)."Inorganic Electronic Spectroscopy". Elesevier, $11^{\text {th }}$ ed., New York. pp.355362.

Lever, A.B.P.(1984). "Inorganic Spectroscopy". Elsevier: Amsterdam, The Netherlands.

Matrtell, A.E.(1971)."Coordination Chemistry ".Van Nostr and Renhold, New York. I p.

Maurya, M.R.; Khurana, S.; Schulzke, C.; Rehder, D.(2001). Dioxoand Oxovanadium (V) complexes of Biomimetic Hydrzone ONO Donor Ligands: synthesis, characterizatization and reactivity. Eur. J. Inorg.Chem.,3,779-788.

Munde, A.S.; Jagdle, A.N.; Jadhav, S.A.; Chondhekar, T.K. (2010). Synthesis, characterization and thermal study of some transition metal complexes of an asymmetrical tetradentate schiff base ligand, J. Serb.Chem.Soc.,75(3),349-359.

Nejo, A.A.; Kolawole, G.A.; Opoku, R.A.; Muller, C.; Wolowska, J. (2009). Synthesis, characterization, an insulin -enhancing studies of unsymmetrical tetradentate schiff base complexes of Oxovanadium(IV). J. Coord. 62,3411-3424.

Osowole, A.A.(2008). Synthesis and Characterization of some tetradentate schiff base complexes and their heteroleptic analogues. J.Chem.,5(1),130-135.

Padmaja, M.; Pragathi, J.; Kumari, G.C.(2011). Synthesis spectral characterization, molecular modeling and biological activity of frist row transition metal complexes with schiff bases ligand derived from Chromone-3-Carbaldehyde and O-amino Benzoic. Acid.J.Chem.Pharm.Res.,3(4),602.

Pandey, V.; Chawalay; Saraf, S.K.(2012). Comparative study of conventional and microwave assisted synthesis of some schiff bases and their potential as antimicrobial agents. Med. Chem. Res.,21, 844-852.

Pathan, H.A.; Naik, G.N.; Bakale, R.P.; Machakanur, S.S.; Gudasi, K.B. (2012). Ligathional behavior of new mononucleating NOO ethyl pyruvate schiff base towards 3d Metal(II)Ion an emphasis on antiproliferative and photo cleavage property. Appl. Organomet. Chem., 6,148-155.

Pethe, G.B.; Bansod, A.D.; Devhad, J.B.; Maldhure, A.K.; Aswar, S.A. (2017). Synthesis, spectral thermaland biological studies of some unsymmetrical schiff base metal complexes India Res. J.Chem.Sci.,7(1), 8-12.

Pietro, A.V.; Sergio, Y. (2004). The challenge of cyclic and acyclic schiff bases and related derivatives. Coord. Rev., 248,1717-2128.

Raman, N.; Raja, J.D.; Sakthivel, A. (2007). Synthesis, spectral characterization of schiff base transition metal complexes :DNA cleavage and antimicrobial activity studies. J. Chem. Sci., 119,303-310.

Rightto, S.; Di Bella, S. (2014). Synthesis, Characterization, optical absorption fluorescencence spectroscopy, and second-ordernon linear optical properties of aggregate molecular architectures of unsymmetrical schiff -base Zinc(II) complexes. Dallton.Trans., 43 (2), 168-215.(Cross Ref)

Sakunthala, M.; Subramanian, P.(2012). Synthesis, characterization and antimicrobial studies of $\mathrm{Cu}(\mathrm{II}), \mathrm{Ni}(\mathrm{II}), \mathrm{Mn}(\mathrm{II})$ and $\mathrm{Zn}(\mathrm{II})$ schiff base complexes derived from 2hydroxynaphthaldehyde and 1,8-diaminonaphthalene., P.subramanian ${ }^{*}$ et al./International J. Pharmcy and Technol., 4(3),4630-4644.

Shelke, V.A.; Jadhar, S.M.; Patharkar, V.R.; Shankarwar, S.G.; Munde, A.S.; Chonddekar, T.K. (2012). Synthesis, spectroscopic characterization and thermal studies of some rare earth metal complexes of unsymmetrical tetradetate schiff base ligand. Arabian J. Chem., 5, 501-507.

Singh, N.; Singh, N.K.; Kaw, C. (1989). Synthetic and spectroscopic study of xanthate-bridged hetrobimetallic complexes containing diamagnetic and paramagnetic metal Ion. Metal Ions. Bull. Chem. Soc. (Jpn).62,3328-3333.

Srinivasan, N.; Valarmath, P.; Thirumavan, S.; Ciattini, S.(2010). Synthesis and spectral studies on $\mathrm{NiS}_{4}, \mathrm{NiS}_{2} \mathrm{PN}, \mathrm{NiS}_{2} \mathrm{PN}, \mathrm{NiS}_{2} \mathrm{P}_{2}$ chromophres single-crystal X-ray Structure of [Ni(dbpdtc $\left.)^{2}\right]$ $[\mathrm{Ni}(\mathrm{dbpdtc}=(4-($ benzyl amino) phenyl dithio carbamate. Trans Met.Chem.,35, 815-819. 
Wahba, O.A.G.; Hassan, A.M.; Naser, A.M.; Hanafi, A.M.(2017). Preparation and spectroscopic of some Copper and Nickel schiff base complexes and their applications as colouring pigments in protective paints. Industry, Egpypt. J. Chem., 60(1), 25-40.

Yaul, A.R.; Dhande, V.V.; Suryawanshi, N.J.; Aswar, A.S. (2009). Synthesis, structural investigation and biological studies of some transition metal chelates of acid hydrzone. Polish. J. Chem.83, 562-572.

Yaul, A.R.; Pethe, G.B.; Aswar, A.S. (2014). Synthesis, characterization and catalytic studies of some oxovanadium(iv) complexes of tetradentate schiff base ligands, Rev.Roum.Chem.,59(1),15-26.

Zeyrek, C.T.; Elmadi, A.; Elerman, Y.; Svoboda, I. (2005). Crystal structure and magnetic exchange interaction in a binuclear Copper(II) schiff base complexes with abridging mphenylenendiamine. Ligand. Z. Naturforsch., 60b,143-148. 